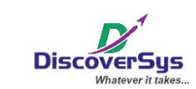

Published by DiscoverSys

\section{Hubungan derajat keparahan preeklamsia dengan kejadian asfiksia neonatorum di Rumah Sakit Umum Negara periode Januari 2019 - Januari 2020}

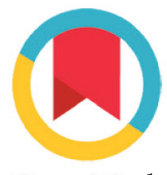

CrossMark

\author{
I Gde Ketut Fendy Indrapermana ${ }^{1 *}$, Iswara Somadina Duarsa ${ }^{2}$
}

\section{ABSTRACT}

Background: Preeclampsia is one of complication in pregnancy and the causal of maternal morbidity and mortality. There is an impairment of blood flow to placenta vascularization which lead to tissue hypoxia and increase the chance to develop asphyxia neonatorum. The aim of this study is to know the correlation between severity of preeclampsia and asphyxia neonatorum in Negara General Hospital on January 2019-January 2020.

Methods: The design of this study was observational analytic cross-sectional. Woman who was diagnosed with preeclampsia and delivered in Negara General Hospital, Jembrana between January 2019-January 2019 were included by total sampling. Data, such as maternal age, parity, mode of delivery, severity of preeclampsia and asphyxia neonatorum, were collected from medical record. Then, data was analyzed bivariate using chi-square test and prevalence

ratio (PR) analysis was conducted. The value of $p<0,05$ was considered significant.

Results: As many as 170 women with preeclampsia were recruited in the study. The prevalence of birth asphyxia was $71,2 \%$ in this study. Majority of women were $20-35$ years old $(67,1 \%)$, parity 2-3 (50,6\%), had assisted-delivery $(74,7 \%)$ and severe preeclampsia (72,9\%). A bivariate analysis showed the prevalence of asphyxia neonatorum was significantly higher in assisteddelivery $(\mathrm{PR}=2,541, \mathrm{p}=0,036 ; 95 \% \mathrm{Cl}=1,044-6,188)$ and severe preeclampsia ( $P R=2,346, p=0,045 ; 95 \% C l=1,044-5,486)$.

Conclusion: Mode of delivery and severity of preeclampsia is associated with asphyxia neonatorum. Early identification and proper antepartum management were essential to prevent asphyxia neonatorum in mother with risk factors.

Keywords: preclampsia, asphyxia neonatorum

Cite This Article: Indrapermana, I.G.K.F., Duarsa, I.S. 2020. Hubungan derajat keparahan preeklamsia dengan kejadian asfiksia neonatorum di Rumah Sakit Umum Negara periode Januari 2019 - Januari 2020. Intisari Sains Medis 11 (3): 1009-1014. D0I: 10.15562/ism.v11i3.840

\section{ABSTRAK}

Latar Belakang: Preeklampsia adalah salah satu komplikasi kehamilan dan penyebab morbiditas dan mortalitas maternal. Kondisi ini menyebabkan gangguan aliran darah ke vaskularisasi plasenta sehingga dapat menimbulkan hipoksia jaringan dan berpotensi menyebabkan asfiksia neonatorum. Penelitian ini bertujuan untuk mengetahui hubungan antara derajat keparahan preeklampsia dan kejadian asfiksia neonatorum di Rumah Sakit Umum (RSU) Negara.

Metode: Penelitian ini menggunakan rancangan analitik observasional desain potong-lintang. Sampel penelitian adalah wanita yang terdiagnosis dengan preeklampsia dan menjalani persalinan di RSU Negara, Jembrana dalam kurun waktu Januari 2019 - Januari 2020 yang dikumpulkan secara total sampling. Data berupa usia maternal, paritas, metode persalinan, derajat preeklampsia, dan kejadian asfiksia neonatorum didapatkan dari rekam medis. Data kemudian dianalisis secara bivariat dengan uji chi-square dan dilakukan analisis prevalence ratio (PR). Hubungan dikatakan signifikan apabila diperoleh nilai $p<0,05$.

Hasil: Penelitian ini mengikutsertakan 170 pasien yang memenuhi kriteria inklusi dan eksklusi. Sebanyak 71,2\% kejadian asfiksia neonatorum tercatat dalam penelitian ini. Mayoritas ibu berusia 20-35 tahun (67,1\%), memiliki paritas 2-3, melakukan persalinan dengan tindakan $(74,7 \%)$, dan mengalami preeklampsia berat (72,9\%). Berdasarkan hasil uji bivariat, prevalensi kejadian asfiksia neonatorum lebih tinggi pada persalinan dengan tindakan ( $P R=2,541, p=0,036$; Confidence interval $(\mathrm{Cl}) 95 \%$ 1,044-6,188) dan preeklampsia berat ( $P R=2,346, p=0,045 ; C \mid$ 95\% 1,044-5,486). Simpulan: Metode persalinan dan derajat preeklampsia berhubungan dengan kejadian asfiksia. Deteksi dini dan penanganan anterpartum yang tepat dapat membantu mencegah kejadian asfiksia neonatorum pada ibu yang berisiko. 


\section{PENDAHULUAN}

Hipertensi Dalam Kehamilan (HDK) merupakan suatu kondisi terjadinya peningkatan tekanan darah pada masa kehamilan yang ditandai dengan tekanan darah sistolik $\geq 140 \mathrm{mmHg}$ dan/atau diastolik $\geq$ $90 \mathrm{mmHg}$, di mana pengukuran tekanan darah dilakukan pada dua kali pemeriksaan den waktu 4-6 jam. ${ }^{1,2}$ Sindroma preeklampsia (PE) merupakan salah satu kategori HDK, yakni terjadinya HDK pada usia kehamilan $\geq 20$ minggu, yang disertai dengan salah satu kondisi berupa proteinuria, tanda disfungsi organ maternal, atau disfungsi uteromaternal. ${ }^{3-5}$

Hipertensi berkontribusi sebagai komplikasi pada $5-10 \%$ kehamilan dan merupakan salah satu dari tiga penyebab morbiditas dan mortalitas maternal selain perdarahan dan infeksi. ${ }^{4-6}$ Berdasarkan penelitian di Rumah Sakit Umum Pusat (RSUP) Sanglah pada tahun 2011, didapatkan prevalensi HDK keseluruhan adalah sebesar 9,32\%, dengan prevalensi PE ringan sebesar 1,36\% dan PE berat sebesar $4,7 \%{ }^{7}$

Manifestasi klinis PE yang terjadi pada wanita hamil seringkali lambat terdeteksi sehingga tanpa disadari dalam waktu singkat dapat timbul keadaan yang dapat membahayakan ibu dan janin. Munculnya PE pada kehamilan dapat menyebabkan komplikasi pada ibu serta dapat pula menyebabkan gangguan kesejahteraan terhadap janin. Salah satu komplikasi neonatal akibat faktor risiko PE adalah terjadinya asfiksia neonatal. ${ }^{8,9}$ Asfiksia neonatal dapat menyebabkan sekuele secara sistemik akibat penurunan aliran darah dan/atau oksigen bagi neonatus selama periode peripartum. Sebagai akibatnya, asfiksia dianggap sebagai penyebab penting morbiditas dan mortalitas pada neonatus. ${ }^{10,11}$

Beberapa penelitian sebelumnya telah dilakukan untuk menilai faktor risiko PE pada ibu terhadap kejadian asfiksia neonatorum., ${ }^{9,12,13}$ Penelitian yang lebih spesifik oleh Kongwattanakul dkk ${ }^{14}$ secara signifikan menemukan bahwa pada ibu yang mengalami PE berat dan dengan komplikasi sindroma hemolysis, elevated liver enzyme, and low platelet counts (HELLP) cenderung lebih berisiko melahirkan neonatus yang mengalami asfiksia dibandingkan dengan ibu yang hanya mengalami PE ringan. Adapun penelitian mengenai hubungan antara derajat keparahan PE dan asfiksia neonatorum belum pernah dilakukan di institusi penulis. Dengan demikian, peneliti tertarik melakukan penelitian untuk mengetahui hubungan antara derajat keparahan preeklampsia dan asfiksia neonatorum di Rumah Sakit Umum (RSU) Negara, Bali pada periode Januari 2019 sampai dengan Januari 2020.

\section{METODE}

Penelitian ini merupakan penelitian analitik observasional desain potong lintang. Penelitian dilakukan di Departemen Ilmu Kebidanan dan Kandungan RSU Negara selama periode Januari 2019 hingga Januari 2020. Data demografik yang akan dicatat pada subjek penelitian ini berupa usia maternal, paritas, metode persalinan, derajat preeklampsia, dan kejadian asfiksia neonatorum. Sumber data dalam penelitian ini berupa data sekunder yang berasal dari rekam medis pasien. Persetujuan penelitian dan penggunaan rekam medis telah disetujui oleh kepala bagian Departemen Ilmu Kandungan dan Kebidanan RSU Negara dan Komite Etik RSU Negara, Jembrana, Bali.

Besar sampel pada penelitian ini sebesar 170 sampel, yang dipilih dengan teknik total sampling dan memenuhi kriteria inklusi dan eksklusi. Kriteria inklusi dalam penelitian ini adalah: wanita hamil yang sudah menikah, terdiagnosis dengan preeklampsia dan menjalani persalinan di RSU Negara, Jembrana dalam periode waktu yang ditentukan. Kriteria ekslusi adalah subyek yang memiliki keadaan atau penyakit lain yang dapat mengganggu pengukuran dan interpretasi data, misalnya menderita kondisi kesehatan lain atau penyakit penyerta selama masa kehamilan, dan data rekam medis medis pasien tidak lengkap.

Data yang telah dikumpulkan selanjutnya diolah dan dianalisis secara univariat dan bivariat. Variabel yang diuji pada penelitian ini meliputi derajat keparahan preeklampsia sebagai variabel bebas dan kejadian asfiksia neonatorum sebagai variabel tergantung. Analisis data ini dilakukan dengan bantuan perangkat lunak menggunakan Statistical Package for the Social Science (SPSS) versi 21. Uji hipotesis dalam penelitian ini menggunakan uji chi-square. Hubungan dikatakan signifikan apabila diperoleh nilai $\mathrm{p}<0,05$.

\section{HASIL}

Penelitian ini mengikutsertakan sebanyak 170 pasien yang didiagnosis dengan preeklampsia dan melakukan persalinan di RSU Negara selama periode pengumpulan data. Karakteristik sampel penelitian dapat dilihat dalam Tabel 1.

Berdasarkan Tabel 1, rerata usia maternal adalah $31,29( \pm 6,85)$ tahun, yang kemudian dikelompok menjadi dua kelompok. Sebanyak 32,9\% berada dalam kategori usia $<20$ tahun atau $>35$ tahun dan sisanya sebanyak $67,1 \%$ sampel berada dalam kategori usia 20-35 tahun. Sebagian besar pasien memiliki paritas sejumlah 2-3 anak (50,6\%) dan sisanya sejumlah $49,4 \%$ memiliki seorang anak 
(primipara) atau sudah memiliki $>3$ anak. Mayoritas pasien dalam penelitian ini melakukan persalinan dengan tindakan (seksio sesarea, vacuum, atau forcep) yakni sejumlah 74,7\%. Derajat preeklampsia dalam penelitian ini dibedakan menjadi preeklampsia dan preeklampsia berat berdasarkan diagnosis dalam rekam medis. Sebanyak 72,9\% pasien mengalami preeklampsia berat. Bayi yang lahir dari sampel penelitian ini sebagian besar tidak mengalami asfiksia neonatorum (71,2\%).

Berdasarkan Tabel 2, sebanyak 8,8\% bayi yang mengalami asfiksia neonatorum berasal dari

Tabel 1. Karakteristik Sampel Penelitian

\begin{tabular}{lcc}
\hline \multicolumn{1}{c}{ Karakteristik } & $\begin{array}{c}\text { Frekuensi } \\
(\mathbf{N = 1 7 0 )}\end{array}$ & $\begin{array}{c}\text { Persentase } \\
\text { (\%) }\end{array}$ \\
\hline Usia & 56 & 32,9 \\
$<20$ atau $>35$ tahun & 114 & 67,1 \\
20-35 tahun & & \\
Paritas & 84 & 49,4 \\
1 atau $>3$ & 86 & 50,6 \\
2-3 & & \\
Metode Persalinan & 127 & 74,7 \\
Tindakan & 43 & 25,3 \\
Spontan & & \\
Derajat Preeklampsia & 124 & 72,9 \\
Preeklampsia berat & 46 & 27,1 \\
Preeklampsia & & \\
Asfiksia Neonatorum & 49 & 28,8 \\
Ya & 121 & 71,2 \\
Tidak & & \\
\hline
\end{tabular}

ibu yang berusia $<20$ tahun atau $>35$ tahun dan 20,0\% berasal dari ibu yang berusia 20-35 tahun. Berdasarkan uji bivariat, tidak terdapat perbedaan yang bermakna pada kejadian asfiksia neonatorum antara ibu yang memiliki usia $<20$ tahun atau $>35$ tahun dan usia 20-35 tahun ( $>>0,05)$. Sebanyak $14,7 \%$ bayi yang mengalami asfiksia neonatorum berasal dari ibu dengan jumlah paritas 1 atau $>3$, sedangkan sebanyak 14,1\% berasal dari ibu dengan paritas yang tidak berisiko yakni 2-3 (Tabel 2). Tidak ada perbedaan yang bermakna pada kejadian asfiksia neonatorum antara ibu yang memiliki paritas 1 atau $>3$ anak dan paritas $2-3$ anak $(p>0,05)$.

Berdasarkan Tabel 2, sebanyak 24,7\% bayi yang mengalami asfiksia neonatorum lahir dengan tindakan (seksio sesarea, ekstraksi forsep atau ekstraksi vacuum), sedangkan sebanyak 4,1\% lahir spontan. Terdapat perbedaan yang bermakna pada kejadian asfiksia neonatorum antara ibu yang melahirkan spontan dan dengan tindakan $(\mathrm{p}<0,05)$. Anak yang lahir dari persalinan dengan tindakan memiliki prevalensi kejadian asfiksia 2,541 kali lebih tinggi dibandingkan dengan persalinan spontan ( $\mathrm{p}=0,036$; CI 95\% 1,044-6,188). Sebanyak $24,1 \%$ bayi yang mengalami asfiksia neonatorum lahir dari ibu dengan preeklampsia berat, sedangkan sebanyak 4,7\% dari ibu dengan preeklampsia (Tabel 2). Terdapat perbedaan yang bermakna pada kejadian asfiksia neonatorum antara ibu dengan derajat preeklampsia berat dan preeklampsia $(\mathrm{p}<0,05)$. Anak yang lahir dari dari ibu dengan preeklampsia berat memiliki prevalensi kejadian asfiksia 2,346 kali lebih tinggi dibandingkan ibu dengan preeklampsia $(\mathrm{p}=0,045$; CI 95\% 1,044-5,486).

Tabel 2. Hubungan Variabel dengan Asfiksia Neonatorum

\begin{tabular}{|c|c|c|c|c|c|}
\hline \multirow[b]{2}{*}{ Variabel } & \multirow[b]{2}{*}{ Usia } & \multicolumn{2}{|c|}{ Asfiksia Neonatorum } & \multirow[b]{2}{*}{ Nilai p } & \multirow[b]{2}{*}{ PR (Cl 95\%) } \\
\hline & & $\begin{array}{c}\text { Ya } \\
\text { n (\%) }\end{array}$ & $\begin{array}{l}\text { Tidak } \\
\text { n (\%) }\end{array}$ & & \\
\hline \multirow{3}{*}{ Usia } & $<20$ atau $>35$ tahun & $15(8,8)$ & $41(24,1)$ & \multirow{3}{*}{0,681} & \multirow{3}{*}{$0,861(0,421-1,759)$} \\
\hline & & & & & \\
\hline & 20-35 tahun & $34(20,0)$ & $80(47,1)$ & & \\
\hline \multirow{3}{*}{ Paritas } & 1 atau $>3$ & $25(14,7)$ & $59(34,7)$ & \multirow{3}{*}{0,789} & \multirow{3}{*}{$1,095(0,564-2,126)$} \\
\hline & & & & & \\
\hline & $2-3$ & $24(14,1)$ & $62(36,5)$ & & \\
\hline \multirow{3}{*}{ Metode persalinan } & Tindakan & $42(24,7)$ & $85(50,0)$ & \multirow{3}{*}{0,036} & \multirow{3}{*}{$2,541(1,044-6,188)$} \\
\hline & & & & & \\
\hline & Spontan & $7(4,1)$ & $36(21,2)$ & & \\
\hline \multirow{3}{*}{ Derajat preeklampsia } & Preeklampsia & $8(4,7)$ & $38(22,4)$ & \multirow{3}{*}{0,045} & \multirow{3}{*}{$2,346(1,004-5,486)$} \\
\hline & & & & & \\
\hline & Preeklampsia Berat & $41(24,1)$ & $83(48,8)$ & & \\
\hline
\end{tabular}




\section{PEMBAHASAN}

Preeklampsia merupakan komplikasi kehamilan yang dapat menimbulkan bahaya bagi ibu dan janin. Preeklampsia diklasifikasikan menjadi preeklampsia dan preeklampsia berat berdasarkan tekanan darah pasien, dimana istilah preeklampsia ringan digantikan dengan preeklampsia. ${ }^{15}$ Penelitian ini mengikutsertakan 170 sampel ibu yang terdiagnosis preeklampsia atau preeklampsia berat dan melakukan persalinan di RSU Negara selama Januari 2019-Januari 2020 kemudian melihat kejadian asfiksia neonatorum pada bayi. Mayoritas sampel dalam penelitian ini terdiagnosis dengan preeklampsia berat (72,9\%). Prevalensi kejadian asfiksia neonatorum lebih tinggi pada ibu dengan preeklampsia berat dibandingkan dengan preeklampsia. Asfiksia neonatorum merupakan penyebab utama kematian neonatus dan menyebabkan sekitar $31,6 \%$ kematian neonatal. ${ }^{16}$ Pada neonatus yang mengalami asfiksia, diperkirakan sebesar $15-20 \%$ di antaranya mengalami mortalitas pada periode neonatal, dan sebesar 25\% dari yang hidup seringkali mengalami komplikasi defisit neurologis permanen. ${ }^{11}$ Asfiksia neonatorum merupakan kegagalan untuk menginisiasi dan mempertahankan pernapasan pada periode baru lahir. Kejadian asfiksia neonatorum pada dalam penelitian ini cukup rendah yakni $28,8 \% .^{17}$

Beberapa penelitian sebelumnya telah dilakukan untuk menilai faktor risiko preeklampsia pada ibu terhadap kejadian asfiksia neonatorum. Penelitian oleh Utomo ${ }^{9}$ di RS Dr. Soetomo Surabaya menemukan bahwa preeklampsia secara signifikan meningkatkan risiko terjadinya asfiksia neonatorum sebesar 2,3 kali lebih besar dibandingkan dengan pada neonatus dengan ibu yang tidak mengalami preeklampsia. Penelitian oleh Dhamayanti $\mathrm{dkk}^{13}$ juga secara signifikan menemukan bahwa pada ibu yang mengalami preeklampsia berisiko sebesar 2,9 kali melahirkan bayi dengan asfiksia neonatorum dibandingkan dengan pada ibu yang tidak mengalami PE. Penelitian yang lebih spesifik oleh Kongwattanakul $\mathrm{dkk}^{14}$ secara signifikan menemukan bahwa pada ibu yang mengalami preeklampsi berat dan dengan komplikasi sindroma HELLP (hemolysis, elevated liver enzyme, dan low platelet counts) cenderung lebih berisiko melahirkan neonatus yang mengalami asfiksia dibandingkan dengan ibu yang hanya mengalami preeklampsia. Hasil yang berbeda ditampilkan dalam penelitian Dewi dan Rinki ${ }^{18}$ di Jakarta yang menunjukkan bahwa pada neonatus dengan asfiksia ditemukan lebih banyak ibu yang mengalami preeklampsia berat dibandingkan preeklampsia ringan, namun hasil ini tidak berbeda signifikan.
Adanya abnormalitas pada invasi tophoblast dari arteri decidual maternal pada preeklampsia dapat menurunkan perfusi plasenta yang mengakibatkan iskemik plasenta relatif. Kondisi tekanan yang tinggi juga menyebabkan berkurangnya aliran darah ke vaskularisasi plasenta. Tekanan darah yang lebih tinggi pada preeklampsia berat memiliki kemungkinan untuk menimbulkan gangguan aliran darah yang lebih berat. Disfungsi endotel dapat menimbulkan gangguan keseimbangan kadar hormon vasokonstriksi dan vasodilatasi. Vasokonstriksi vaskular menimbulkan rendahnya aliran darah ke plasenta sehingga terjadi asfiksia janin. Ketidakmampuan neonatus setelah dilahirkan untuk bernapas normal karena gangguan pertukaran oksigen dari ibu ke janin sehingga terdapat gangguan ketersediaan oksigen dan pengeluaran karbon dioksida dan terjadi asfiksia neonatus. ${ }^{8,17}$

Penelitian ini menunjukkan bahwa sebanyak 67,1\% ibu berusia 20-35 tahun dan usia ibu tidak berhubungan dengan kejadian asfiksia neonatorum. Hasil ini sesuai dengan penelitian oleh Kardana ${ }^{19}$ di RSUP Sanglah Denpasar yang menunjukkan bahwa usia ibu, yakni $<16$ atau $\geq 35$ tahun dan 16-34 tahun tidak berhubungan dengan kejadian asfiksia perinatal. Beberapa penelitian lain juga menunjukkan bahwa kejadian usia maternal bukan merupakan faktor predisposisi terjadinya asfiksia neonatus. ${ }^{12,20,21}$ Hasil yang berbeda didapatkan dari penelitian oleh Abdo, dkk ${ }^{17}$ yang menunjukkan bahwa usia maternal $\geq 35$ enam kali lebih sering mengalami asfiksia dibandingkan dengan kelompok berusia 20-34 tahun. Usia maternal $<18$ tahun atau $>35$ tahun diketahui dapat meningkatkan risiko kejadian preeklampsia dan kondisi patologis lainnya dalam kehamilan berdasarkan beberapa literatur. $^{3}$

Prevalensi paritas yang dianggap berisiko (1 atau $>3$ ) dan tidak berisiko (2-3) dalam penelitian ini cukup berimbang dan tidak berbeda signifikan dalam kejadian asfiksia neonatroum. Hasil ini sesuai dengan penelitian di Indonesia bahwa tidak ada korelasi pada jumlah paritas dan asfiksia. ${ }^{21}$ Hasil yang berbeda ditunjukkan dalam penelitian oleh Woday $\mathrm{dkk}^{22}$ di rumah sakit umum di Ethiopia, dimana kejadian asfiksia neonatorum pada ibu dengan primipara adalah 3,7 kali lebih banyak dibandingkan ibu multipara. Penelitian di Karachi, Pakistan juga menunjukkan bahwa bayi dari wanita primipara memiliki risiko 2,64 kali lebih tinggi untuk mengalami asfiksia dibandingkan dengan wanita multipara. ${ }^{12}$ Penelitian oleh Abdo, dkk ${ }^{17}$ menunjukkan bahwa asfiksia neonatus terjadi lima kali lebih sering pada primigravida. Ibu dengan primipara cenderung mengalami malpresentasi 
dan partus lama sehingga hal ini dianggap dapat menimbulkan risiko asfiksia perinatal yang lebih tinggi dibandingkan dengan wanita multipara. ${ }^{12}$ Ibu diketahui akan membentuk antibodi namun di sisi lain Human Leucocyte Antigen Protein (HLA) $\mathrm{G}$ berkerja pada imunitas maternal sehingga dapat menimbulkan penolakan dari tubuh ibu terhadap hasil konsepsi atau intoleransi terhadapa plasenta yang menimbulkan preeklampsia. ${ }^{12}$

Sebanyak $74,7 \%$ pasien dalam penelitian melakukan persalinan dengan tindakan (seksio sesarea, vacuum atau forceps) dan sisanya sebanyak $25,3 \%$ melakukan persalinan spontan pervaginam. Kejadian asfiksia neonatus ditemukan dua kali lebih tinggi pada ibu dengan metode persalinan dengan tindakan dibandingkan spontan. Hasil ini didukung oleh penelitian di RSUP Sanglah Denpasar pada 70 neonatus dimana anak yang dilahirkan dengan bantuan alat memiliki risiko mengalami asfiksia 5,51 kali dibandingkan anak yang lahir tanpa bantuan alat. Penelitian ini mengklasifikasikan tindakan vacuum dan forcep kedalam persalinan dengan alat. ${ }^{19}$ Penelitian berbasis rumah sakit lainnya juga memiliki hasil yang sama, yakni penggunaan ekstraksi vacuum dan seksio sesarea memiliki risiko sekitar dua kali untuk terjadinya asfiksia pada neonatus. ${ }^{23}$

Hubungan persalinan seksio sesarea dengan kejadian asfiksia juga telah diteliti sebelumnya. Penelitian oleh Gebreheat $\mathrm{dkk}^{24}$ menunjukkan bahwa neonatus yang lahir dengan seksio sesarea memiliki risiko tujuh kali mengalami asfiksia perinatal dibandingkan dengan yang lahir spontan pervaginam. Hasil yang sama juga didapatkan dari penelitian oleh Utomo ${ }^{9}$ yang menunjukkan bahwa persalinan dengan seksio sesarea memiliki risiko sebesar 3,7 kali untuk terjadinya asfiksia. Penelitian oleh Woday, $\mathrm{dkk}^{22}$ menunjukkan hasil yang berbeda yakni persalinan dengan seksio sesarea bukan sebagai predikor independen dari asfiksia neonatorum. Peningkatan risiko asfiksia pada seksio sesarea biasanya berkaitan dengan tindakan kegawatdaruratan. Seksio sesarea elektif ditemukan memiliki efek protektif karena dapat menghindari risiko komplikasi lainnya yang mungkin terjadi dalam proses intrapartum..$^{25}$

Data mengenai preeklampsia sebagai faktor risiko kejadian asfiksia cukup banyak diteliti, namun apakah derajat preeklampsia akan berhubungan dengan kejadian asfiksia masih sedikit dipahami. Penelitian ini menyediakan data tersebut sebagai acuan untuk mengantisipasi prognosis bayi pada kondisi preeklampsia. Penelitian ini masih memiliki beberapa kekurangan, yaitu: 1) rancangan penelitian yang bersifat potong lintang sehingga tidak memungkinkan penilaian hubungan sebab-akibat antara preeklampsia dan asfiksia, 2) variabel independen yakni derajat preeklampsia hanya diklasifikasikan sebagai preeklampsia dan preeklampsia berat, sedangkan kondisi hipertensi dalam kehamilan lainnya cukup banyak terjadi dan sering tumpang-tindih atau sebagai perjalanan penyakit dari preeklampsia, dan 3) jumlah sampel yang didapatkan dalam penelitian ini relatif sedikit oleh karena teknik sampling yang menggunakan total sampling, dimana jumlah sampel sama dengan populasi, sehingga sebaiknya digunakan teknik sampling lain seperti probability sampling.

\section{SIMPULAN}

Berdasarakan uji bivariat dalam penelitian ini, metode persalinan dan derajat preeklampsia berhubungan dengan kejadian asfiksia neonatorum. Prevalensi kejadian asfiksia neonatorum lebih tinggi pada persalinan dengan tindakan dan preeklampsia berat. Deteksi dini dan penanganan anterpartum yang tepat dapat membantu mencegah kejadian asfiksia neonatorum pada ibu yang berisiko.

\section{UCAPAN TERIMA KASIH}

Ucapan terima kasih penulis berikan kepada pasien RSU Negara dan Departemen Ilmu Kandungan dan Kebidanan, RSU Negara atas kesempatan dan bimbingan yang telah diberikan dalam penulisan penelitian ini.

\section{KONFLIK KEPENTINGAN}

Penulis menyatakan tidak terdapat konflik kepentingan (conflict of interest) pada penulisan laporan penelitian ini.

\section{PENDANAAN}

Penulis bertanggung jawab terhadap seluruh pembiayaan dalam pembuatan laporan penelitian ini.

\section{KONTRIBUSI PENULIS}

Penulis bertanggung jawab dalam pembuatan dan penulisan laporan penelitian ini.

\section{DAFTAR PUSTAKA}

1. Angsar MD. Hipertensi dalam Kehamilan. Dalam: Ilmu Kebidanan Sarwono Prawirohardjo. Ed. 3 Cet. 4. Jakarta (Indonesia): Bina Pustaka Sarwono Prawirohardjo; 2010. hal. 530-560.

2. Kemenkes RI. Buku Saku Pelayanan Kesehatan Ibu di Fasilitas Kesehatan Dasar dan Rujukan. Jakarta (Indonesia): Kementrian Kesehatan Republik Indonesia; 2013. hal. 109117. 
3. American College of Obstetricians and Gynecologists, American Academy of Pediatrics. The Apgar Score. Committee Opinion. 2015;644.

4. Aronow WS. Hypertensive disorders in pregnancy. Ann Transl Med. 2017; 5(12):266.

5. Braunthal S, Brateanu A. Hypertension in pregnancy: Pathophysiology and treatment. SAGE Open Med. 2019; 7.

6. Cunningham FG, Gant NF, Leveno, KJ, et al. William's Obstetric 24th Edition. New York: McGraw Hill Education; 2014. hal. 728-770.

7. Sutopo H, Surya IGP. Characteristics of patients with hypertension in pregnancy at Sanglah Hospital. Indones $J$ Obstet Gynecol. 2011; 35(3):97-99.

8. Kusumaningrum RY, Murti B, Praasetya H. Low Birth, Prematurity, and Pre-Eclampsia as Risk Factors of Neonatal Asphyxia. Journal of Maternal and Child Health. 2019; 4(1): 49-54

9. Utomo MT. Risk Factors for Birth Asphyxia. Folia Medica Indonesiana. 2011; 47(4): 211-214

10. Boskabadi H, Ashrafzadeh F, Doosto H, Zakerihamidi M. Assessment of risk factors and prognosis in asphyxiated infants. Iran J Pediatr. 2015; 25(4):2006.

11. Gillam-Krakauer M, Gowen Jr CW. Birth Asphyxia. [Online]. Treasure Island (FL): StatPearls Publishing; 2020 [diakses pada: 17 Maret 2020]. Tersedia pada: https://www. ncbi.nlm.nih.gov/books/NBK430782/.

12. Aslam HM, Saleem S, Afzal R, et al. Risk factors of birth asphyxia. Italian Journal of Pediatrics. 2014;1-9.

13. Dhamayanti M. Hubungan Preeklampsia dengan Kejadian Asfiksia Neonatorum pada Bayi Baru Lahir di RSUD Wonosari Tahun 2017 [Skripsi]. Yogyakarta (Indonesia): Repository Politeknik Kesehatan Kementrian Kesehatan; 2018.

14. Kongwattanakul K, Saksiriwuttho P, Chaiyarach S, Thepsuthammarat K. Incidence, characteristics, maternal complications, and perinatal outcomes associated with preeclampsia with severe features and HELLP syndrome. Int J Womens Health. 2018; 10:371-377.

15. Perkumpulan Obstetri dan Ginekologi Indonesia. Diagnosis dan Tatalaksana Preeklamsia. Himpunan Kedokteran Feto Maternal. 2016. Hal: 6-8

16. World Health Organization. MCEE-WHO methods and data sources for child causes of death 2000-2015
(Global Health Estimates Technical Paper WHO/HIS/ HSI/GHE/2016.1). Geneva: Department of Information, Evidence and Research WHO; 2016

17. Abdo RA, Halil HM, Kebede BA, et al. Prevalence and contributing factors of Birth asphyxia among the neonates delivered at Negest Eleni Mohammed memorial teaching hospital, Southern Ethiopia: A cross-sectional study. BMC Pregnancy and Childbirth. 2019;19:536.

18. Dewi RK, Rinki MV. The impact of the degree of preeclampsia on neonatal asphyxia in dr. dradjat prawiranegara hospital, serang. Jurnal Bina Cendikia Kebidanan. 2016; 2(2): 180-187

19. Kardana IM. Risk factors of perinatal asphyxia in the term newborn at sanglah general hospital, bali-indonesia. Bali Med J. 2016; 5(1): 196-199

20. Nayeri F, Shariar M, Dalili H, et al. Perinatal risk factors for neonatal asphyxia in Vali-e-Asr hospital, Tehran-Iran. Iran J Reprod Med. 2012; 10(2): 137-140

21. Opitasari C. Maternal education, prematurity, and the risk of birth asphyxia in selected hospital in Jakarta. Health Science Journal of Indonesia. 2015; 6(2): 111-115

22. Woday A, Muluneh A, St Denis C. Birth asphyxia and its associated factors among newborns in public hospital, northeast Amhara, Ethiopia. PLoS ONE. 2019; 14(12): e0226891.

23. Kaye D. Antenatal and intrapartum risk factors for birth asphyxia among emergency obstetric referrals in Mulago Hospital, Kampala, Uganda. East Afr Med J. 2003; 80:140-3.

24. Gebreheat G, Tsegay T, Kiros D, et al. Prevalence and Associated Factors of Perinatal Asphyxia among Neonates in General Hospital of Tigray, Ethiopia. Biomed Research International. 2018;1-8

25. Rachatapantanakorn O, Tongkumchum P, Chaisuksant Y. Factors associated with birth asphyxia. Songkla Med J. 2005; 23 (1): 17-27.

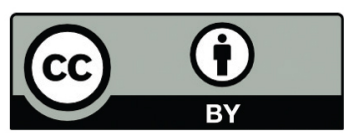

This work is licensed under a Creative Commons Attribution 